The Tang Center for Early China at Columbia University was founded in 2015 through a generous endowment gift from Oscar Tang and Agnes Hsu-Tang. The Tang Center is dedicated to the advancement of the understanding of the richness and importance of early Chinese civilization as a part of a broader common human heritage. It is committed to doing so through both solid scholarship and broad public outreach. The Tang Center sponsors a variety of conferences, workshops as well as public lectures each year including the Columbia Early China Seminar. The Tang Center is especially interested in supporting research initiatives that aim to examine newly discovered paleographic and textual material as well as artifacts, and in promoting the role of archaeology as a path to understand the past.

\title{
Call for Manuscripts
}

\section{Tang Center Series in Early China}

Sponsored by the Tang Center and to be published by Columbia University Press, the "Tang Center Series in Early China" includes new studies that make major contributions to our understanding of early Chinese civilization or that which break new theoretical or methodological grounds in Early China studies. The series is especially interested in publishing works that analyze newly discovered paleographic and manuscript materials as well as archaeological data. Disciplinary focuses of the series are history, archaeology, art history, anthropology, literature, philosophy, and the history of sciences and technology. The series spans from the Neolithic period to the end of the Han Dynasty (AD 220), or to the end of the Tang Dynasty (AD 907) for titles in archaeology. All submissions are subject to peer reviews and editorial evaluation. For more information, please see http://tangcenter-columbia. org/publications/. Interested authors should submit a book proposal (maximum 25 manuscript pages), accompanied by CV, to: info@tangcenter-columbia.org, or by mail to: 509 Kent Hall, 1140 Amsterdam Avenue, MC 3907, Columbia University, New York, NY 10027.

\section{Call for Applications}

\section{The Tang Post-Doctoral Research Award in Early China Studies}

The Tang Center for Early China offers one Post-Doctoral Research Award in the amount of $\$ 15,000$ each year in recognition of outstanding research projects in early Chinese civilization or in archaeology.

\section{The Tang Visiting Scholar's Fellowship}

The Tang Center offers Visiting Scholar's Fellowship each year to one scholar for an in-residence research period of 10 months at Columbia University, or to two scholars for a period of 5 months each, depending on the need of the proposed projects. The applicant must be non-US based.

\section{Workshop and Conference Grants}

The Tang Center offers grants in the amount of $\$ 13,000$ each to up to two workshop and/or conference proposals each academic year, depending on the scale. Each workshop or conference should have an identified central problem or theme on which the papers will focus. Alternatively, the workshop/ conference can be centered on a newly discovered corpus of materials or manuscripts, or on an important archaeological site, or a region.

Application deadline, November 30 , for all programs.

For more information, please visit our website www.tangcenter-columbia.org. Questions directed to: info@tangcenter-columbia.org; or by phone: 212.854.5546.

509 Kent Hall, MC3907, 1140 Amsterdam Avenue, New York, NY 10027 


\section{Archaeology Books and Journals from Cambridge University Press}

Cambridge publishes books and journals that cover research throughout world archaeology and across all periods.

Our list includes key handbooks and manuals in method, theory and scientific techniques; case studies of sites, surveys and excavations; comparative and interpretative works; scholarship on cultural resource management, and large scale, reliable reference works.

For further details visit:

cambridge.org/core-archaeology

\section{Cambridge} Mis 140 


\begin{abstract}
ing and indexing
Articles published in Early China are indexed by Scopus, CrossRef, Google Scholar, the Bibliography of Asian Studies, MLA International Bibliography, the European Reference Index for the Humanities and Social Sciences (ERIH PLUS), and PIO - Periodicals Index Online.
\end{abstract}

\title{
Photocopying information
}

All rights reserved. No part of this publication may be reproduced, in any form or by any means, electronic, photocopying or otherwise, without permission in writing from Cambridge University Press. Permission to copy (for users in the USA) is available from Copyright Clearance Center, http:/ /www.copyright.com, email: info@copyright.com. 


\section{Early China}

Volume 40, 2017

\section{Guidelines for Preparation of Manuscripts}

Early China is a specialized journal devoted to the archaeology, art, history, language, literature, philosophy, religion, science and technology of China from the Neolithic through the Han. Published annually by the Society for the Study of Early China and Cambridge University Press, it includes articles based on original research, occasional translations of seminal articles written in Chinese, reviews of scholarship including both Westernlanguage monographs and developments in China, Taiwan and Japan, and comprehensive bibliographies of works in Western languages. Contributors need not be members of the Society for the Study of Early China, but all submissions other than those expressly commissioned by the editorial board are subject to peer review.

Submissions for future issues should be sent, in triplicate, to Professor Sarah Allan, Editor, Early China, Dept. of Asian and Middle Eastern Languages and Literatures, HB 6191 Dartmouth College, Hanover, NH 03755, USA. Electronic submissions are also acceptable and may be sent to: sarah.allan@ dartmouth.edu in both Word document and PDF formats. As manuscripts are reviewed anonymously, please remove the author's name from the manuscript and any identifying references in the footnotes (such as "see my article $x x^{\prime \prime}$ ). Books for review should be sent to the Book Review Editor, Professor Anne Kinney, 4185 Garth Road, Charlottesville, VA 22901, USA.

For further information, please visit www.cambridge.org/eac.

\section{Subscription information}

Early China is published once a year (September) by Cambridge University Press, One Liberty Plaza, New York, NY 10006, USA.

The subscription price of Volume 40 (2017) including delivery by air where appropriate (but excluding VAT), is $\$ 132$ (£83.00) for institutions print and online; \$122.00 ( $£ 76.00$ ) for institutions online only.

Orders, which must be accompanied by payment, may be sent to a bookseller, subscription agent or direct to the publisher: Cambridge University Press, Journals Fulfillment Department, One Liberty Plaza, New York, NY, 10006, USA; or Cambridge University Press, UPH, Shaftesbury Road, Cambridge CB2 8RU, England.

For single issues, please contact subscriptions_newyork@cambridge.org

\section{Advertising}

For information on display ad sizes, rates, and deadlines for copy, please contact USAdSales@cambridge.org.

Postmaster: Send address changes to: Early China, Cambridge University Press, Journals Fulfillment Department, 100 Brook Hill Drive, West Nyack, NY 10994-2133. 


\section{CONTENTS}

Letter from the Editor: Early China at 40

Sarah Allan

OBITUARY

David Noel Keightley (1932-2017) Sarah Allan, Miranda Brown,

Roderick B. Campbell, Jonathan Chaves, Constance A. Cook, Lothar von Falkenhausen, Marián Gálik, Zev Handel, Kuan-yun Huang, Lionel M. Jensen, Steven I. Levine, Li Ling, Li Xueqin, Edward L. Shaughnessy, Frank Joseph Shulman

David Noel Keightley (1932-2017), Publications and Unpublished Writings: A Bibliography and Research Guide

Frank Joseph Shulman

ARTICLES, EXCAVATED TEXT TRANSLATION, RESEARCH NOTE

Early Chinese Manuscript Writings for the Name of the Sage

Emperor Shun 舜, and the Legacy of Warring

States Period Orthographic Variation in Early

Chinese Received Texts Adam D. Smith

Mozi and the Ghosts: The Concept of Ming 明 in Mozi's

“Ming gui" 明鬼” Piotr Gibas

Echoing Rulership: Understanding Musical References in the Huainanzi

Avital H. Rom

Introduction to the Peking University Han Bamboo

Strips: On the Authentication and Study

of Purchased Manuscripts Christopher J. Foster

The Wuwei Medical Manuscripts: A Brief Introduction

and Translation Yang Yong and Miranda Brown

To Punish the Person: A Reading Note Regarding

a Punctuation Mark in the Tsinghua

Manuscript ${ }^{*}$ Ming Xun Edward L. Shaughnessy

BOOK REVIEWS \& BIBLIOGRAPHY

Durrant, Li, Nylan, and Ess. The Letter to Ren An and

Sima Qian's Legacy Lei Yang

Barbieri-Low and Yates. Law, State, and Society in Early

Imperial China

Charles Sanft

Dissertation Abstracts and Annual Bibliography Wen-Yi Huang, comp. 